\title{
Increasing College-Going Rate, Parent Involvement, and Community Participation in Rural Communities
}

\author{
Stephanie B. King \\ Mississippi State University
}

This study examined the perceptions of leaders of grant-supported projects aimed at increasing the college-going rate of high school students in rural Appalachian counties in Mississippi to determine which factors they felt most influenced the college-going rate, parental participation in school activities, and community participation. Analysis of the leaders' responses to questions related to these items showed that college visits and ACT preparation workshops were perceived as having the greatest impact on increasing the college-going rate at the schools. No one factor was perceived as having the least impact on increasing the college-going rate at the schools. Factors influencing parental and community participation included events and workshops for parents, especially those which involved community members as mentors.

Keywords: College attendance; high school students; family environment; academic aspiration; rural education; parental participation; community participation.

A number of influences have been identified as playing a role in rural students' decisions to attend college. The student's family, including their education levels and their support for the student to attend college, seem to play the strongest role. Student and family financial resources and information about obtaining financial aid also influence a student's decision. In addition, the student's experiences in high school, including curriculum, and the student's perceptions of his or her ability to succeed in college and to benefit from higher education play a role. As a result, a number of public and private programs have been developed to increase the number of rural students choosing to attend college. Strategies have varied, and some of the most beneficial have been shown to include relationships with peers and mentors who encourage the student to attend college, providing the parents and student with information about the requirements for attending college, and providing the parents and student with information about and assistance with completing admissions and financial aid forms (The National Center for Education Evaluation, 2009).

\section{Literature Review}

Numerous factors influence students' decisions to attend college, but the influence of family is particularly strong. According to the National Postsecondary Education Cooperative (2007), "For traditional-aged students, across ethnic and racial categories and regardless of SES, parents play the strongest role in the college choice and decisionmaking processes" (p. 39). Rural youth are no exception. In a study of youth from a rural
Appalachian area of North Carolina, findings indicated that both parent and community education levels impacted the youths' college aspirations. More youth from communities and families with adults who had at least a two-year degree indicated that they had set a goal of getting a college degree (Brown, Copeland, Costello, Erkanli, \& Worthman, 2009). Research on high school students from a rural Appalachian area of West Virginia demonstrated a relationship between plans to attend college and (a) having parents and extended family members who had attended college and (b) fathers who were employed in a professional occupation (Chenoweth \& Galliher, 2004). In addition, parental support for attending college plays a role in rural students' decisions to attend college. Ali and Saunders (2006) found that rural Appalachian high school students were more likely to expect to attend college if they felt they had parental support.

Having financial resources and information about how to obtain financial assistance also plays a role in students' decisions to attend college. In a study of rural West Virginia high school seniors, students reported various problems related to making decisions about attending college. The most commonly cited problem related to not having financial resources, followed by not having information about college and not having information about financial aid (Chenoweth \& Galliher, 2004). Across the United States, Grodsky and Jones (2007) found that parents who have low socioeconomic status and minority parents are "less likely to provide estimates of college tuition and, when they provide estimates, tend to make larger errors" (p. 745). 
Other influences include students' experiences in high school, including the curriculum, as well as their perceptions of their ability to succeed in college and the benefit of attending college. In a study of high school students from a rural Appalachian area, Chenoweth and Galliher (2004) highlighted several factors that influence college attendance decisions. Planning to attend college was related to students' "(a) ultimate educational goals, (b) high school curriculum, (c) perceptions of preparedness, and (d) perceived intelligence" (p. 5) as was "comfort in the school setting" (p. 10). Attewell and Domina (2008) found that students with a lower socioeconomic status tend to choose a less demanding curriculum and that taking a more demanding curriculum affects the likelihood of college entry and completion. Also, Hardré, Sullivan, and Crowson (2009) found that rural high school students' perceptions of the value and benefit of the knowledge and skills taught and the importance and usefulness of the material delivered were predictors of their plans to attend postsecondary education. The students were more likely to plan to attend postsecondary education if they "felt competent and believed they could learn and develop skills in a school subject" (p. 13).

However, more rural youth are planning to attend college. A study of rural Pennsylvania high school seniors (Legutko, 2008) that compared the postsecondary plans of students in 1995 and 2005 indicated more students were planning to attend college in 2005, while the numbers of students who did not plan post-secondary education and who were unsure of their plans decreased. Also, more students whose parents had no postsecondary education were planning to attend college. Finally, more lowermiddle class students were planning to attend college (Legutko, 2008).

Numerous strategies may be used to increase the college-going rate among students. Research shows that relationships with adults and other students who will support, guide, and positively influence students in their efforts to attend college may increase the college going rate of students (The National Center for Education Evaluation, 2009). The National Center for Education Evaluation recommends that to increase college access, schools should "surround students with adults and peers who build and support their college-going aspirations" (p. 6). In addition, the American Youth Policy Forum (Hooker \& Brand, 2009) found that mentoring and other relationships was one of the most cited elements for contributing to students' attendance and success in college.

Providing students and parents with information about the academic requirements of college and the steps necessary for college entrance are important. In addition, providing assistance with the process of applying for college and obtaining financial aid is beneficial. According to the National Center for Education Evaluation (2009), the two key issues related to increasing the number of students attending college are (a) ensuring students are academically prepared and (b) guiding students to take the appropriate steps for college entrance. Additionally, they recommend that schools endeavor to make families more financially aware and provide help for students in the process of applying for financial aid.

In a study conducted with $9^{\text {th }}$ and $11^{\text {th }}$ grade students in five states, Bell, Rowan-Kenyon, \& Perna (2009) found that generally students lacked knowledge about college, especially about financial aid. Students mostly obtained information about college from their families, the Internet, and the school and expressed a need for personal and active methods of obtaining information at the school. Although the $11^{\text {th }}$ grade students had a greater awareness of college and obtained information from formal sources such as the school, in general, students received little information prior to the senior year. Students in early intervention programs knew more about financial aid. The degree of their awareness was influenced by their socioeconomic status. Bell et al. (2009) noted a "lack of consistent mechanisms in most schools to channel information to students about the breadth of available educational opportunities available and the availability of financial aid and how to access it" (p. 677).

Providing assistance in completing application forms is beneficial. The National Center for Education Evaluation (2009) recommended that schools "engage and assist students in completing critical steps for college entry" in order to increase college access (p. 6). The federally supported Talent Search Program provides assistance in the completion of college and financial aid applications and college visits. Participants in the program were more likely to enroll in postsecondary education and to apply for financial aid (Constantine, Seftor, Martin, Silva, \& Myers, 2006).

Plank and Jordan (2001) found that students who received more information and guidance were more likely to enroll in 4-year postsecondary educational institutions full-time as opposed to 2-year institutions full-time, 2-year institutions part-time, or not enroll. While communication among students, parents, and school personnel was important in the college-going decision-making process, assistance in applying for financial aid and admission, and in preparing for and taking the SAT/ACT had even greater effects.

Barriers to students with lower socioeconomic status are less when information, guidance, and actions were included (Plank \& Jordan, 2001). Finally, rigorous curriculum that prepares students for 
college-level work in conjunction with support services and assessment of progress, are also important components in college-going decisions and future success at the post-secondary level (The National Center for Education Evaluation, 2009). Schools should "offer courses and curricula that prepare students for college-level work and ensure that students understand what constitutes a collegeready curriculum by 9th grade" (National Center for Education Evaluation, 2009, p.6). Students must be aware of the degree to which they are prepared for the rigors of college; it is the school's responsibility to ensure that any deficiencies are identified and addressed. The American Youth Policy Forum (Hooker \& Brand, 2009) found that one of the most often cited elements contributing to students attending and succeeding in college was "Rigor and Academic Support" (p. vii), which referred to curriculum, instruction, and other academic services.

\section{Educational Attainment in Rural Appalachia}

Residents in rural Appalachia have lower levels of educational attainment than residents in other areas of the United States. While the college-going rate of high school graduates nationwide is above 60 percent, the Appalachian Regional Commission estimates the rate is between 35 and 55 percent in Appalachia (Schwartz, 2004). And, while 27.5 percent of the United States population ages 25 and over have attained a bachelor's degree or higher, only 20.4 percent of the population in the Appalachian region has done so. In addition, only 15.8 percent of the population ages 25 and over in Appalachian Mississippi has attained a bachelor's degree or higher (Pollard \& Jacobsen, 2011).

The current study examined Mississippi communities that were part of the Appalachian Higher Education Network (AHEN). Inaugurated in 2000, AHEN's mission is to increase the collegegoing rate and raise the education attainment levels of students in Appalachian communities. Centers for advancing this mission have been established in many of the states served by the Appalachian Regional Commission, and they have been successful in increasing the college-going rate in these states. Schwartz (2004) noted that an "increased number of students attending some form of postsecondary education has been carefully documented" (p. 16). In 2009, seven Mississippi communities were awarded grants of approximately $\$ 10,000$ per year for two years to develop and conduct programs to increase the college-going rate of the students in their local public schools. In 2010, four additional grants were awarded. Communities were required to model successful activities at other AHEN centers. The communities used project-sponsored activities including parent and community participation and included such activities as college visits, workshops for students and parents, and mentoring programs. In addition to funds for programs, personnel at the university overseeing the project provided the communities with technical assistance.

\section{Method}

The leaders of each of eleven grant-supported projects aimed at increasing the college-going rate of high school students in rural Appalachian counties in Mississippi were asked to complete an annual report form as part of the conditions of receiving the grant. Ten of the project leaders gave the researcher permission to include their responses in future research studies. Two of the project leaders responded that they were unable to completely implement the project during the year and did not provide responses to all of the questions.

As part of the annual report, grant leaders addressed the following four questions; they were not limited in the number of items they could identify on each question.

1. What factors had the greatest impact on increasing the college-going rate at your school?

2. What activities had the least impact? In other words, what did not work well?

3. Did you have improved parental participation in school activities? If yes, please share what worked and what did not?

4. Since this is a community-based project, describe community participation. Did you meet your expectations? What worked and what did not? What did you learn about getting community involvement in this program?

The researcher analyzed the responses given by each leader and noted patterns in the data. Responses were examined to determine the leaders' perceptions about which factors they felt impacted the college-going rate at their schools, parental participation in school activities, and community participation.

\section{Findings}

The findings were organized according to the themes noted in the data analysis.

\section{Factors with Most Impact on College-going Rate}

Data analysis showed that participants perceived certain factors as more influential than others in influencing the college-going rate.

Factors listed by the greatest number of respondents as having the most impact on college-going rates 
were college campus visits (7), followed by ACT preparation workshops (5). Two respondents each listed offering financial aid workshops and providing workshops related to college attendance for school personnel.

The number of campus visits indicated by respondents ranged from two to six, with a mean of four. Of the postsecondary institutions visited, 58 percent were universities and 42 percent were community colleges. In five of the eight projects, all seniors participated in at least one campus visit. One respondent noted that "the college visits helped our students experience what it was like to be at a college campus. Many of our students had never been on a campus. For them to experience it, they can now visualize themselves being there." Another commented, "Our students desperately need the exposure to different college environments. While the local community college is ideal for most of our students, others would thrive in a bigger school setting. Just being able to visit the other colleges around the state helped many of our students want to attend college."

The ACT preparation workshops were important to ensure students met requirements to apply to postsecondary institutions. One respondent noted, "The $\mathrm{ACT}$ is also something that can stand in the way of students going to college, so by helping students get signed up, offering tutoring sessions, and providing a hot meal and transportation on the day of the test, we were able to promote the college-going thinking of the participants."

Financial aid workshops had an impact by providing assistance to parents and students, many of whom were unfamiliar with not only the completion of the paperwork, but also the use of the computer. One respondent noted, "The FAFSA nights were very important, because FAFSA can be difficult to navigate and having the mentors there to assist the families helped ensure that they would complete the paperwork." Another respondent noted that because of their workshop on financial aid, "parents realized financial help for college was available."

Providing workshops for school personnel had an impact by providing them with information about the project as well as general information about college attendance. One respondent noted that "inservice sessions with school administrative staff and senior class sponsors" was one factor having the greatest impact at his school.

Other factors noted included assistance with ACT sign-up, transportation to ACT testing site, mentors, goal setting meetings, career information, college week (e.g., completion of resume, applications, letters), community service, program Web site, visits by college representatives, awarding college t-shirts, encouraging students to wear apparel with college logos, job shadowing, and mentor assistance with FAFSA completion.

\section{Factors with Least Impact on College-going Rate}

While respondents listed several factors they perceived had the least impact on increasing the college-going rate at the school, there was no commonality and no one factor was identified more than once. Items listed included the financial aid workshop. Reasons for why the financial aid workshop was unsuccessful included it was offered too late and that it was not well-attended. Linked to the financial aid workshop was offering financial aid completion assistance for people not comfortable with computers. One respondent noted, "Many people did not want to work on the computers and were not comfortable with the format of the event. Because of reluctance to work on computers, many attendees wanted the instructor to work step-by-step on the paper version of the applications."

Other factors reported to have low impact were providing career information, college visits, and mentor socials. One respondent noted that although the career information software that they used was interesting for the students and provided information about educational requirements for various careers, using the software did not change students' attitudes about going to college. College visits were perceived as having the least impact by one respondent who emphasized the consequences of choosing students who were not qualified to attend a given college for a visit to that college. She reported behavior problems during the visits from some of those students and speculated the problems were due to the fact that the students knew they would not be attending the college and were thus not interested in learning about the college. For future campus visits to ensure that college visits were perceived to be valuable, project leaders required students attending to have the qualifications to attend that specific college. Mentor socials were perceived as being less valuable, as rather than socialize, mentors preferred to work with students and parents on specific projects. As one respondent commented, "We believe that the volunteers wanted time to really 'matter' and so they would come to the events where they were doing something, like helping the student complete a FAFSA or study for the ACT or visit a college for the first time."

\section{Improved Parental Participation}

Respondents indicated the importance of hosting events and workshops for parents and noted useful 
strategies to increase attendance, including making sure parents knew about the events and providing food. One respondent noted, "We basically started with little to no parent participation. We were diligent about making contacts and saw significant improvements." Another respondent commented, "We saw several parents that came to [our] programs that we had otherwise not seen at school events." Most of the respondents indicated that because of the initiatives they put in place, they had improved parental participation in school activities related to post-secondary opportunities. Most respondents indicated that hosting events and workshops for parents had been effective, and providing food at events was an added incentive; two respondents specifically observed the effectiveness of sending invitations and notices to parents about events. In addition, providing mentors to assist parents at workshops to complete the FAFSA was successful. Activities such as using parents as chaperones on campus visits and involving parents in assembling care packages for students receiving acceptance letters to college were also deemed successful. One respondent noted that they held a back-to-school rally and had good participation; it was the first of this type of activity to be held at their school.

\section{Involving the Community}

As part of the requirements of the grant, each school worked with a community-based group in the planning and implementation of the project activities. Throughout the reporting period, some schools had successful working relationships with community members and were able to work with those entities in their efforts. Other schools faced challenges in determining roles and responsibilities for the various partners.

Respondents were asked to indicate if they met their community participation expectations. Of the five respondents who directly indicated if they met their expectations for community participation, two indicated they did not while three indicated they did. One respondent indicated that they had "outstanding community support" with involvement of city officials, business owners, government employees, and school district personnel.

Respondents noted successful methods for encouraging community participation. One respondent indicated that emailing community members with requests did not work, while making requests one-on-one was more effective. In particular, contacting a variety of community members was most effective in increasing community involvement and resulted in " new" volunteers who weren't as busy with other organizational commitments." One leader noted the benefit of searching for and contacting potential community volunteers who may not have been involved in other community service activities and thus had more time to devote to the students. One respondent indicated, "We learned that it is important to locate someone in the community who is as motivated and committed to improving life of young people."

When asked about which activities worked and which did not to increase community participation, respondents' answers about what worked primarily pertained to community members' participation in various events held at the school. Respondents noted community members' participation in college or reality fairs as well as serving as judges for exit projects presentations. Community members also helped plan and host activities such as awards banquets, workshops for parents and students, and campus visits. One respondent noted, "Having the key activities and recruiting a diverse and qualified group of mentors had the greatest impact on affecting our college-going rate."

\section{Discussion}

The leaders' perceptions of the factors having the greatest impact on increasing the college-going rate at their schools corresponded to the research related to increasing the college-going rate among rural students. Respondents indicated the importance of involving mentors, providing opportunities for job shadowing, supplying career information, and hosting a college week at the school. This is in agreement with recommendations by the National Center for Education Evaluation (2009) that high schools "surround students with adults and peers who build and support their college-going aspirations." In addition, this is consistent with findings by Hooker and Brand (2009) that mentoring and other relationships contributed to students' attendance and success in college. According to the United States Department of Agriculture Economic Research Service (2009), average earnings and education levels are substantially lower for non-metro workers. Rural students may be at a disadvantage when making college attendance decisions because their family and community members have low levels of educational attainment. Perhaps mentors and other community members provided the information and encouragement that many rural students' parents were unable to provide.

Respondents also indicated the importance of college campus visits, ACT preparation workshops, workshops related to college attendance for school personnel, assistance with ACT sign-up and 
transportation to ACT testing site, and visits by college representatives. This is in agreement with recommendations by the National Center for Education Evaluation (2009) that high schools "engage and assist students in completing critical steps for college entry." As Bell et al. (2009) reported, students often lack knowledge about college entry. Perhaps exposure to the college environment and personnel helped students make a personal connection to the college and gave them an opportunity to see themselves as students in that environment. Further, providing students assistance with taking required entrance exams may have prompted them to take that necessary step toward college entry, something they might have delayed if left to do so on their own.

In addition, respondents indicated the importance of financial aid workshops and mentor assistance with FAFSA completion. As recommended by the National Center for Education Evaluation (2009), high schools should 'increase families' financial awareness, and help students apply for financial aid." As reported by Chenoweth and Galliher (2004), rural students had numerous problems when making decisions about attending college, but two of the most common were having financial resources and having information about financial aid. Conceivably, rural students and their parents should be provided information about obtaining financial aid as well as hands-on assistance in completing the necessary steps.

Factors noted as least effective were sometimes related to local issues. One respondent noted that participants completing financial aid forms were not comfortable with computers. Perhaps offering basic computer training as part of the workshop would have helped parents feel more comfortable with the technology. In addition, providing financial aid workshops early enough in the school year for students to meet scholarship and other deadlines is beneficial. With respect to student behavior problems on college campus visits a suggestion was that in the future, only students who were qualified to attend that college would be allowed to participate in a visit to that college. One respondent indicated that mentor socials had the least impact; she went on to state that mentors preferred activities in which they were directly involved in helping the students rather than only socializing. Perhaps students and mentors felt uncomfortable or that they were not using the time wisely when socializing.

Parental support is crucial in rural students' decisions to attend college. The National Postsecondary Education Cooperative (2007) reported that parents play the strongest role in decisions about college attendance. In addition, the
National Center for Education Evaluation (2009) has shown that providing students and their parents with information about the college admissions process and involving mentors are important. As a result, one focus of this project was to improve parental participation. The respondents noted the importance of providing workshops for parents and of making sure that parents were aware of those workshops and providing food. Some respondents noted the effectiveness of providing mentors to assist parents at workshops and involving parents in college campus visits. Perhaps other efforts to involve parents in school activities would impact parental support for college attendance as well.

Community support of school efforts to increase college attendance is also important. Both the National Center for Education Evaluation (2009) and Hooker and Brand (2009) note the importance of mentoring relationships on students' college attendance decisions. In this study, methods to increase community participation emphasized finding those volunteers who had the time and passion for helping the students. While some schools were successful in working with community members, other schools faced challenges in building these relationships. Perhaps time and additional efforts to make those connections would increase levels of community support. In addition, conceivably, those schools who were successful may share best practices with schools struggling to build these relationships.

\section{Implications}

There are numerous influences on the educational aspirations of rural youth, and a number of strategies may be used to encourage these rural youth to pursue higher education. College campus visits provide students, some of whom have never experienced a college campus, with a glimpse of what they are like and may help make students feel more at ease about attending college. ACT preparation workshops, and other assistance with taking the test, may help students increase their test scores and may prod reluctant or procrastinating students to sign up for and take the ACT test. Workshops for students, parents, and school personnel are important to provide understanding of college entrance requirement and procedures for obtaining financial aid. Involving the community through long-term relationships such as mentoring, as well as more short-term encounters such as career fairs or job shadowing, are also important components to help rural students connect to professionals who can encourage and assist them as they make decisions 
and take necessary steps to attend college.

This study examined the perceptions of leaders of grant-supported projects aimed at increasing the college-going rate of high school students in rural Appalachian counties. There were some limitations to the study, including the lack of conclusive data for the change in the college-going rate at each school at

\section{References}

Ali, S. R., \& Saunders, J. L. (2006). College expectations of rural Appalachian youth: An exploration of social cognitive career theory factors. The Career Development Quarterly, 55(1), 38-51.

Attewell, P., \& Domina, T. (2008). Raising the bar: Curricular intensity and academic performance. Educational Evaluation and Policy Analysis, 30(1), 51-71.

Bell, A. D., Rowan-Kenyon, H. T., \& Perna, L. W. (2009).College knowledge of $9^{\text {th }}$ and $11^{\text {th }}$ grade students: Variation by school and state context. The Journal of Higher Education, 80(6), 663685.

Brown, R., Copeland, W. E., Costello, E. J., Erkanli, A., \& Worthman, C. M. (2009). Family and community influences on educational outcomes among Appalachian youth. Journal of Community Psychology, 37(7), 795-808.

Chenoweth, E., \& Galliher, R. V. (2004). Factors influencing college aspirations of rural West Virginia high school students. Journal of Research in Rural Education, 19(2). Retrieved from http://jrre.psu.edu/articles/19-2.pdf

Constantine, J. M., Seftor, N. S., Martin, E. S., Silva, T., \& Myers, D. (2006). A study of the effect of the Talent Search Program on secondary and postsecondary outcomes in Florida, Indiana and Texas: Final report from phase II of the national evaluation. Princeton, NJ: Mathematica Policy Research.

Grodsky, E., \& Jones, M. T. (2007). Real and imagined barriers to college entry: Perceptions of cost. Social Science Research, 36(2), 745-766.

Hardré, P., Sullivan, D., \& Crowson, H. (2009). Student characteristics and motivation in rural high schools. Journal of Research in Rural the time the project leaders completed the report and the fact that the information is based on the selfreported perceptions of each project leader. Despite these limitations, the information provided by the project leaders may be useful in guiding others working with similar projects.

Education, 24(16). Retrieved from http://jrre.psu.edu/articles/24-16.pdf

Hooker, S., \& Brand, B. (2009). Success at every step: How 23 programs support youth on the path to college and beyond. Washington, DC: American Youth Policy Forum.

Legutko, R. S. (2008). A decade's difference: Research revisited on family influence of rural high school students' postsecondary decisions. The Rural Educator, 29(2), 4-7.

National Center for Education Evaluation. (2009). Helping students navigate the path to college: What high schools can do. Washington, DC: Author.

National Postsecondary Education Cooperative. (2007). Deciding on postsecondary education: Final report (NPEC 2008-850). Washington, DC: Author.

Plank, S. B., \& Jordan, W. J. (2001). Effects of information, guidance, and actions on postsecondary destinations: A study of talent loss. American Education Research Journal, 38(4), 947-979.

Pollard, K., \& Jacobsen, L. A. (2011). The Appalachian region in 2010: A census data overview chartbook (CO-16506-09). Washington, DC: Appalachian Regional Commission.

Schwartz, J. H. (2004). Development and progress of the Appalachian Higher Education Network. Washington, DC: Appalachian Regional Commission.

United States Department of Agriculture Economic Research Service. (2009). Rural labor and education. Retrieved from http://www.ers.usda.gov/briefing/LaborAndEduc ation/

\section{About the author:}

Stephanie King is an Assistant Research Professor in Leadership and Foundations at Mississippi State University. Her research interests are: Articulation to and from the community college and community development and the role of the community college.

Acknowledgement: This research was supported by Appalachian Regional Commission Grant MS-16115. 